\title{
OUTBREAK OF BOTULISM IN CATTLE IN AN AREA OF THE NORTHEAST REGION OF BRAZIL
}

\author{
Francisco Feliciano da SILVA JÚNIOR ${ }^{1}$; José Andreey Almeida TELES ${ }^{2}$; Fábio Denilson de \\ Oliveira FELICIANO ${ }^{3}$; Catharina de Paula Oliveira Cavalcanti SOARES ${ }^{4}$; Marcos Antônio \\ Leal FERREIRA ${ }^{5}$; Gil Dutra FURTADO ${ }^{6}$
}

\begin{abstract}
${ }^{1}$ Graduado em Medicina Veterinária/Universidade Federal Rural de Pernambuco (UFRPE); Especialista em Clínica Médica de Ruminantes/Universidade Estadual Paulista Júlio de Mesquita Filho (UNESP); Mestre em Medicina Veterinária Preventiva e Saúde Pública/UNESP; Doutor em Medicina Veterinária Preventiva e Saúde Pública/UNESP; Médico Veterinário Autônomo. E-mail: felicianojr@yahoo.com.br

${ }^{2}$ Graduado em Medicina Veterinária/Universidade Federal de Campina Grande (UFCG); Especialista em Doenças Infectocontagiosas dos Animais Domésticos/UFRPE; Mestre em Biociência Animal/UFRPE; Doutor em Ciências Veterinária/UFRPE. Coordenador e Docente do Curso de Medicina Veterinária/Centro Universitário Maurício de Nassau João Pessoa-PB (UNINASSAU). E-mail: teles.jaa@ gmail.com

${ }^{3}$ Professor Titular do Departamento de Ciências da Informação/Instituto Federal de Pernambuco (IFPE), Belo Jardim, Brasil. E-mail: fabio.feliciano@belojardim.ifpe.edu.br

${ }^{4}$ Enfermeira/Centro Universitário CESMAC, Maceió, Brasil; Mestrado Profissional em Ciências e Saúde/CESMAC. E-mail: inacavalcanti@hotmail.com

${ }^{5}$ Laboratório de Biotecnologia Celular/Universidade de Ciências da Saúde de Alagoas (UNCISAL), Brasil. Email: marcosvet@hotmail.com

${ }^{6}$ Discente do Curso de Medicina Veterinária da Faculdade Maurício de Nassau (UNINASSAU); Engenheiro Agrônomo/Universidade Federal da Paraíba (UFPB); Doutor em Psicobiologia/Universidade Federal do Rio Grande do Norte (UFRN); Agrônomo-Sócio da Cooperativa de Agronegócio (COOPAGRO). E-mail: gdfurtado@hotmail.com
\end{abstract}

\begin{abstract}
Botulism is an intoxication caused by the ingestion of a neurotoxin produced by Clostridium botulinum, an anaerobic, Gram-positive bacteria which can sporulate in adverse conditions. This work intends to report a surge of botulism in the city of União dos Palmares, Alagoas, Brazil, which occurred in an area of milk cows with 45 animals, 14 of which had died, showing signs of weakness of the hind limbs, and in 4 cases evolved over a period of 30 days, some with profuse, brownish-green, foul-smelling diarrhea, aside from progressive weight loss. An autopsy was performed on one of the sick animals, of which no significant lesions were observed. Samples of intestinal contents were collected and centrifuged to remove supernatant and later the biological test, inoculation of mice, was performed. This test confirmed the outbreak of the disease on the property studied. Clostridium botulinum was present on the property studied, causing the outbreak of botulism. The main factor initiating the appearance of the surge was the inadequate handling of carcasses and
\end{abstract}


the presence of contaminated water reservoirs. The laboratory diagnosis was of great importance in verifying a clinical suspicion.

Keywords: Improper handling of carcasses; Contaminated water reservoirs; Dairy cows.

\section{SURTO DE BOTULISMO BOVINO EM UMA LOCALIDADE DA REGIÃO NORDESTE DO BRASIL}

Resumo. O botulismo é uma intoxicação causada pela ingestão de uma neurotoxina produzida por Clostridium botulinum, uma bactéria anaeróbia, Gram positiva, que pode esporular em condições adversas. Este trabalho pretende relatar um surto de botulismo na cidade de União dos Palmares, em Alagoas, Brasil, que ocorreu em uma área de vacas leiteiras com 45 animais, 14 dos quais morreram, apresentando sinais de fraqueza dos membros posteriores, e em 4 casos evoluíram ao longo de um período de 30 dias, alguns com diarreia profusa, verde-acastanhada e com mau cheiro, além da perda de peso progressiva. Uma autópsia foi realizada em um dos animais doentes, dos quais não foram observadas lesões significativas. Amostras de conteúdo intestinal foram coletadas e centrifugadas para remoção do sobrenadante e posteriormente foi realizado o teste biológico, inoculação de camundongos. Este teste confirmou o surto da doença na propriedade estudada. O Clostridium botulinum estava presente na propriedade estudada, causando o surgimento do botulismo. O principal fator que iniciou o surgimento do surto foi o manejo inadequado das carcaças e a presença de reservatórios de água contaminados. O diagnóstico laboratorial foi de grande importância na verificação de suspeita clínica.

Palavras-chave: Manejo inadequado das carcaças; Reservatórios de água contaminados; Vacas leiteiras.

\section{SURTO DE BOTULISMO BOVINO EN UNA LOCALIDAD DE LA REGIÓN NORDESTE DEL BRASIL}

Resumen. El botulismo es una intoxicación causada por la ingestión de una neurotoxina producida por Clostridium botulinum, una bacteria anaerobia, Gram positiva, que puede esporular en condiciones adversas. Este trabajo pretende relatar un brote de botulismo en la ciudad de Unión de los Palmares, en Alagoas, Brasil, que ocurrió en un área de vacas lecheras con 45 animales, 14 de los cuales murieron, presentando signos de debilidad de los miembros posteriores, y en 4 casos evolucionaron a lo largo de un período de 30 días, algunos con diarrea profusa, verde-pardusco y con mal olor, además de la pérdida de peso progresiva. Una autopsia se realizó en uno de los animales enfermos, de los cuales no se observaron lesiones significativas. Las muestras de contenido intestinal fueron recolectadas y centrifugadas para retirar el sobrenadante y posteriormente se realizó la prueba biológica, inoculación de ratones. Esta prueba confirmó el brote de la enfermedad en la propiedad estudiada. El Clostridium botulinum estaba presente en la propiedad estudiada, causando el surgimiento del botulismo. El 
principal factor que inició el surgimiento del brote fue el manejo inadecuado de las canales y la presencia de depósitos de agua contaminados. El diagnóstico de laboratorio fue de gran importancia en la verificación de sospechas clínicas.

Palabras clave: Manejo inadecuado de las canales; Depósitos de agua contaminados; Vacas lecheras.

\section{INTRODUCTION}

Botulism is an intoxication caused by the ingestion of neurotoxins produced by Clostridium botulinum, a strictly anaerobic, Gram-positive, bacteria that can sporulate in adverse conditions. There exists six types of $C$. botulinum, classified A to $\mathrm{G}$, according to the production of toxins, where toxins $\mathrm{A}, \mathrm{B}, \mathrm{E}$, and $\mathrm{F}$ are frequently responsible for botulism in humans and types $\mathrm{C}$ and D responsible for the disease in animals (ACHA \& SZYFRES, 1986; BÖHNEL, 1999; GARRITY, 2005; REBHUN-WILLIAM, 2000; SMITH; SUGIYAMA, 1988).

Botulinic intoxication is considered and important cause of mortality in cattle in many countries in the southern hemisphere. In Brazil, it was first registered in the region of Campo Maior, in the state of Piauí, at the end of the 1960s, being designated at that occasion as the "hard hand disease". In the 1970s, 1980s and up to the mid-1990s, botulism was responsible for great surges in the west-central and southeast regions of the country. Estimates indicate that more than 6 million animals died between 1985 and 1999 due to intoxication in these regions (DÖBEREINER; DUTRA, 2004).

Botulism does not have geographic limits, ocurring in isolated cases and sporatic surges in most countries. The source of exposure to the toxin and the risk of disease differ between regions due to distinct ways of stocking food, feeding and handling practices (RADOSTITS et al., 2002).

The neurotoxins, produced during vegetative growth, form spores that can survive in the environment for over thirty years. Under favorable humidity and temperature conditions, the spores germinate, and the cells rapidly multiply, producing a stable, highly lethal toxin that causes disease when ingested or absorbed by tissues. The spores of the microorganism can be encountered ubiquitously in soil, water, animal and vegetable organic material, in canned food, the digestive tract of humans and animals (RADOSTITS et al., 2002; SMITH, 1977).

Aside from the unsanitary handling, the most common contribution to the animals contracting the disease consists in the incomplete nutritional administration. Phosphorus 
deficiency, caused by lack of quality mineral supplementation, is a predisposing factor of ingesting the toxin, since it causes the animals to develop the habit of gnawing and ingesting bone fragments of animal carcasses, being of cattle, of other livestock or of wild animals. When this occurs, there is a possibility of ingesting $C$. botulinum spores, which play a role in the epidemiological chain (LEMOS; BONILHA, 1998; TOKARNIA et al., 1970).

In ruminants, intoxication can occur due to the habit of osteophagia or even from the ingestion of feed contaminated with decomposing organic material. Other common sources of the botulinum toxin are food supplements, feed contaminated with animal carcasses, and also wells and lakes with stagnant water (DUTRA et al., 2005). Contaminated silage has been reported to cause botulism outbreaks among cattle (MYLLYKOSKI et al., 2009).

Epidemiological data shows a higher incidence of the disease in pregnant or lactating adult females and with a higher frequency registered in rainy seasons, which can be explained by the greater nutritional requirement of this animal category and by the difficulty of mineral supplementation during this period (LISBOA et al., 1996; DUTRA et al, 2001).

When ingested and absorbed, the toxins bind to peripheral nervous system receptors, blocking the release of acetylcholine, which acts as a mediator of the nervous impulse, thus causing an episode of flaccid paralysis (CARTER et al., 1991).

The beginning of the clinical signs and their severity are intimately related to the amount of toxin ingested, and the incubation period varies from a few hours to several days. In the initial phase, the animals show a loss in coordination, ataxia and progressive flaccid paralysis, affecting the hind leg muscles first. The paralysis also affects deglutition and mastication, with the occurrence of sialorrhea and protrusion of the tongue. The psyche, on the other hand, remains unaltered. During the final phase, the animal finds itself in the lateral decubitus position and death occurs by respiratory failure. Many times few or no clinical signs are observed, and the animals are found already dead. In the post mortem examination there are no significant alterations, displaying, at the most, a general congestion of the carcass (SMART; ROBERTS, 1997; BIENVENU et al., 1990).

Basic principle of detection and isolation of C. botulinum from clinical, food and environmental samples remained essentially unchanged since its first report (DHAKED et al., 2010).

The diagnosis of the illness is based on the symptoms, the case history and the absence of significant macroscopic lesions. To confirm the clinical diagnosis different techniques are used according to laboratory availability. Interperitoneal inoculation of mice (biological test) with hepatic extract, blood serum, ruminal or intestinal contents is considered to be the most 
specific test, however, it has a low toxicological sensitivity. The laboratory diagnosis can also be done by the complement micro fixation technique induced by heating or by the immunoenzymatic test (FERNANDES, 2007).

Vaccination is the most important prophylactic method. However, one must remember that vaccine protection depends on the dose of toxin ingested, since the animals may develop the disease when exposed to great quantities of the toxin. Other auxiliary methods include the correct stocking of hay, feed and silage, avoiding contamination with decomposing material. Opting for a mineral mixture, along with providing good quality water and food, removal of carcasses and bones from pastures are also important methods, especially for extensively raised ruminants (DÖBEREINER; DUTRA, 2012; LOBATO et al., 1998).

The diagnosis of this intoxication is based on the detection of the botulinum toxin in gastric, intestinal, serum and liver contents of the sick or dead animal, and in the food when there is suspicion of contamination. It can also be done through clinical signs, epidemiology and absence of nervous system lesions. Clinical signs can include permanent sternal decubitus, absence of anal reflex, flaccid paralysis of hind limbs, salivation, relaxation of the mandible and easy exposure of the tongue (GALIZA et al., 2010; BALDASSI et al., 1991).

The treatment for botulism, for herds, is not economically viable, however, general handling and specific vaccinations are prophylactic measures that ought to be taken (BALDASSI et al., 1991).

Having in sight the importance of the illness in the cattle industry and the socioeconomic losses causes, aside from lack of notifications within the state, this study had the objective of reporting an outbreak of botulism that occurred in a property of milk cows in the City of União dos Palmares, Alagoas, Brazil. Thus evaluating not only the clinical findings, but also the epidemiology of the illness on the property demonstrating the occurrence of botulism in the region.

\section{CASE REPORT}

In August, 2012, property owners of a milk farm located in the City of União dos Palmares, Brazil, solicited a technical visit for the study of neurological disorder cases in female cows, with progression to death in some animals and weakness and absence of milk production in those that survived.

According to the owner's report, 14 of 45 animals died, showing signs such as weakening of the hind legs with a progression time of more than 30 days, some with fetid, greenish-brown, profuse diarrhea, along with progressive weight loss. It is interesting to note 
that of three distinct groups of animals, only one group that grazed in a determined area became ill. By observing the signs and information, an outbreak of botulism was suspected, and an epidemiological study of the area was initiated to identify the factors that evidenced conditions favorable to the development of sickness within the herd.

During the investigation of the suspected pastures, the technicians observed water reservoirs covered with native aquatic plants (Fig. 1), where the animals drank daily, and at their banks, animal carcasses (Fig. 2).

In sight of such conditions, one of the animals which was showing symptoms was referred to the University Center Cesmac's School of Veterinary Medicine Clinic to perform specific tests with the objective of diagnosing the case. When the animal arrived at the institution, it was in the sternal decubitus position, showing flaccid paralysis of the hind legs, altered general parameters, dark and fetid diarrhea, second-degree genital discharge and suppurative otitis. Facing these clinical signs, fecal matter was collected for the parasitological and microbiological tests, and the animal was euthanized to be able to perform an autopsy and to collect material for laboratory examination.

The parasitological exam had negative results. The microbiological exam was positive for samples of Salmonella sp. and Escherichia coli.

The autopsy did not show any significant lesions. Samples of intestinal contents were collected and centrifuged. The supernatant was later used for the biological test, inoculation of mice.

The sample used for the diagnosis of the disease was chosen due to the determination of toxin in rumen and/or intestinal contents providing circumstantial evidence for the botulism definitive diagnosis. While the toxin, when encountered in the liver, could have been produced only at the final stage of the disease or post-mortem, which cannot serve as criteria for diagnosis (JONES, 1991).

Two mice with corporal masses of $20 \mathrm{~g}$ and $25 \mathrm{~g}$ were inoculated with $0.5 \mathrm{ml}$ of supernatant by intraperitoneal injection as described by Smith (1997). They presented botulinic intoxication symptoms and death within 48 hours. This last test confirmed the outbreak of the disease on the property studied.

The questioning of one of the owners with respect to not having observed the animals feeding on bones in the pasture was justified by the fact that this outbreak of botulism was from hydric origin (DUTRA et al., 2001) and not because mineral deficiency. Further, the fact that the destination of the carcasses had always been close to the collections of water in the pasture and never having had any instances of the disease before could be explained by the 
occurrence of flooding before the emergence of the cases. This leads one to believe that the toxins were present in a limited amount in the pasture and with the floodwaters, these toxins were disseminated in the whole area.

\section{DISCUSSION}

In Brazil, preliminary sporadic outbreaks of botulism from hydric origin in cattle have been registered in the states of São Paulo and Mato Grosso do Sul Dutra et al. (1990), and Souza et al. (1996) in Goiás. Langenegger e Döbereiner (1988) described outbreaks of endemic botulism in buffalo in Maranhão, relating them to the presence of plant organic material in the ponds formed in drought periods, used by the animals for bathing and drinking. The possibility of having the formation of the botulinum toxin having only cattle feces and rainwater as substrates is still unknown (DUTRA et al., 2005).

Outbreaks of botulism in Mexico typically occur when poultry litter is added to the diet. This form is much common in the Americas than that of the classic botulism seen in Africa and Australia where phosphorous-deficient cattle develop disease and eat botulismcontaminated material (BIENVENU et al., 1990; FITZPATRICK, 2006; JEAN et al., 1995).

The symptomatology of the disease in the animals of the property studied was consistent with the infirmity, seeing that, with an evolution time of 30 days the immunological state of the animal was debilitated favoring secondary infections such as Salmonella sp. In addition, as reported in the literature, the autopsy reveals no significant macroscopic lesions, having the possibility of encountering pieces of bones in the rumen, which is a strong indication of botulinum intoxication by osteophagia. In studies in which autopsy findings were analyzed in animals suspected of botulism, no alterations worthy of note were encountered (DUTRA et al., 2005).

The confirmation of the botulinum toxin was performed by the inoculation of mice, a technique advocated by the Center for Disease Control (CDC) for having high sensitivity, reliability, and specificity (SMITH, 1998; BALDASSI et al., 1991).

\section{CONCLUSIONS}

The biological test showed to be effective since the inoculated mice died showing symptoms of botulinum intoxication, such as elevation of fur, loss of muscle tone in the anal region, and flaccid paralysis of the hind legs, thus confirming the suspicion and concluding the diagnosis of an outbreak of botulism on the property studied. 
The Clostridium botulinun toxin was present on the property studied, initiating an outbreak of botulism. The principal initiating factor for the appearance of the outbreak was an inadequate handling of carcasses and the presence of contaminated water reservoirs. The laboratory diagnosis was of extreme importance for confirming a clinical suspicion.

\section{REFERENCES}

ACHA, P.N.; SZYFRES, B. Zoonosis y enfermidades transmisibles comunes al hombre y a los animales. 2. ed. Washington: OPAS/OMS, 1986.

BALDASSI, L.; HIPOLITO, M.; PORTUGAL, M.A.S.C.; CALIL, E.M.B.; MOULIN, A.A.P.; PIRES, D.C. Botulismo bovino: comprovação laboratorial do diagnóstico clínico, período 1986-1989. Revista de Saúde Pública, São Paulo, v. 25, n. 5, 1991.

BIENVENU, J.G.; MORIN, M.; FORGET, S. Poultry litter associated botulism (type C) in cattle. Canadian Veterinary Journal, v. 31, n. 10, p. 711, 1990.

BÖHNEL, H. Botulism - a forgotten disease? Berliner und Muncher Tierarztliche Wochenschrift, v. 112, p. 139-145, 1999.

CARTER, G.R.; GHENGAPPA, M.M. Clostridia. In: Essential of veterinary bacteriology and mycology. 4th. ed. London: Lea \& Febiger, p. 284, Chap.14. 1991.

DHAKED, R.K.; SINGH, M.K.; SINGH, P.; GUPTA, P. Botulinum toxin: Bioweapon \& magic drug. Indian Journal of Medical Research, v. 132, p. 489-503, 2010.

DÖBEREINER, J.; DUTRA, I. O botulismo dos bovinos e o seu controle. Informe técnico 72, Embrapa Rio de Janeiro. Seropédica. 2004. Disponível em: http://www.cnpab.embrapa.br/publicacoes/. Acesso em: 27 mai 2019.

DUTRA, I.S.; DÖBEREINER, J.; ROSA, I.V.; BOND, V. Botulismo de origem hídrica em bovinos no Brasil. 16th World Buiatrics Congress, Salvador, Bahia, p. 547-550, 1990. 
DUTRA, I.S.; DÖBEREINER, J.; ROSA, I.V.; SOUZA, L.; NONATO, M. Surtos de botulismo em bovinos no Brasil associados à ingestão de água contaminada. Pesquisa Veterinária Brasileira, v. 21, n. 2, p. 43-48, 2001.

DUTRA, I.S.; DÖBEREINER, J.; SOUZA, A.M. Botulismo em bovinos de corte e leite alimentados com cama-de-frango. Pesquisa Veterinária Brasileira, v. 25, p. 115-119, 2005.

FERNANDES, C.G. In: RIET-CORREA, F.C. Doença dos ruminantes e eqüídeos. 3 ed., Santa Maria: Pallotti. p. 220-223, 2007.

FITZPATRICK, S. Botulism poisoning in cattle in the northern territory. Department of Regional Development, Primary Industry, Fisheries and Resources, Northern Territory Government, Serial No. 651, Agdex No. 420/654. 2006.

GALIZA, G.J.N.; SILVA, M.L.C.R.; DANTAS, A.F.M.; SIMÕES, S.V.D.; RIET-CORREA, F.C. Doenças do sistema nervoso de bovinos no Semi-árido. Pesquisa Veterinária Brasileira, v. 30, n. 3, 2010.

GARRITY, G.M. Bergey's manual of systematic bacteriology. 2 ed. New York: Springer, 2005.

JEAN, D.; FECTEAU, G.; SCOTT, D.; HIGGINS, R.; QUESSY, S. Clostridium botulinum type $\mathrm{C}$ intoxication in feedlot steers being fed ensiled poultry litter. The Canadian Veterinary Journal, v. 3, p. 626-628, 1995.

JONES, T.O. Bovine botulism. In Practice, v. 13, n. 3, p. 84-86, 1991.

LANGENEGGER, J.; DÖBEREINER, F. Botulismo enzoótico em búfalos no Maranhão. Pesquisa Veterinária Brasileira, v. 8, n. 1/2, p. 37-42, 1988.

LEMOS, R.A.A.; BONILHA, M.M. Principais enfermidades de bovinos de corte do Mato Grosso do Sul. Universidade Federal de Mato Grosso do Sul, Campo Grande, p. 59-76, 1998. 
LISBOA, J.A.N.; KUCHEMBUCK, M.R.G.; DUTRA, I.S.; GONÇALVES, R.C.; ALMEIDA, C.I.; BARROS FILHO, I.R. Epidemiologia e quadro clínico do botulismo epizoótico dos bovinos no Estado de São Paulo. Pesquisa Veterinária Brasileira, v. 16, n. 2/3, p. 67-74, 1996.

LOBATO, F.C.F.; ALMEIDA, A.C.; ABREU, V.L.V.; SILVA, N.; NASCIMENTO, R.A.; MARTINS, N.E. Potência de toxóides botulínicos bivalentes C e D produzidos e comercializados no Brasil. Revista Brasileira de Medicina Veterinária, v. 20, n. 1, p. 3538, 1998.

MYLLYKOSKI, J.; LINDSTROM, M.; KETO-TIMONEN, R.; SODERHOLM, H.; JAKALA, J.; KALLIO, H.; SUKURA, A.; KORKEALA, H. Type C bovine botulism outbreak due to carcass contaminated non-acidified silage. Epidemiology \& Infection, v. 137, n. 2, p. 284-293, 2009.

RADOSTITS, O.M.; GAY, C.C.; BLOOD, D.C.; HINCHCLIFF, K.W. Clínica veterinária um tratado de doenças dos bovinos, ovinos, caprinos e equinos. 9 ed. Rio de Janeiro: Guanabara/Koogan, p. 680. 2002.

REBHUN-WILLIAM, C. Doenças do gado leiteiro. São Paulo: Roca, 2000.

SMART, J.L.; ROBERTS, T.A. Bovine botulism. Veterinary Record, v. 101, p. 201-202, 1997.

SMITH, L.D. Botulism: the organism, its toxins, the disease. Springfield: Charles C. Thomas. p. 236. 1977.

SMITH, L.D.; SUGIYAMA, H. Botulism: the organism, its toxins, the disease. 2. ed. Springfield: Charles C. Thomas. 1988.

SOUZA, A.M.; MARQUES, D.F.; DUTRA, I.S. Botulismo enzoótico bovino de origem hídrica em Goiás. Anais XXIV Congresso Brasileiro de Medicina Veterinária, Goiânia, Goiás, p. 74. 1966. 
TOKARNIA, C.H.; LANGENEGGER J.; LANGENEGGER C.H.; CARVALHO E.V. Botulismo em bovinos no Piauí, Brasil. Pesquisa Agropecuária Brasileira, v. 5, n. 3, p. 465472, 1970. 